\title{
Mobile city- og sprogguides Nye forbindelser mellem formelle og uformelle læringsmiljøer
}

\section{Mads Bo-Kristensen}

Udviklingskonsulent, ph.d.

Videnscenter for Integration i Vejle (www.vifin.dk) MADBO@vejle.dk

\section{Niels Ole}

\section{Ankerstjerne}

It-udvikler, cand.mag.

Videncenter for Integration i Vejle (www.vifin.dk) NIOAN@vejle.dk

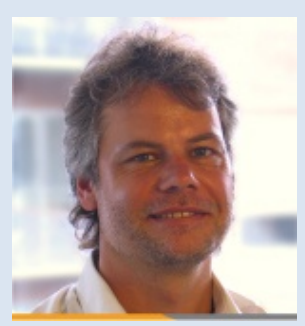

\section{Anne Chresteria}

\section{Neutzsky-Wulff}

Videnskabelig assistent, cand.mag, master i lkt og Læring

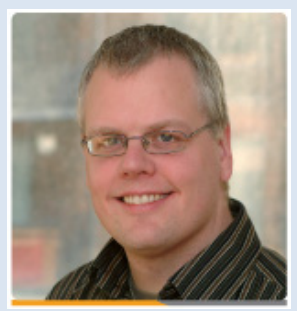
SAXO-Instituttet, Københavns Universitet chresteria@chresteria.dk 


\section{Herluf Schelde}

Underviser, cand.mag.

LærDansk, Århus

(http://laerdansk.dk/aarhus)

herluf.schelde@skolekom.dk

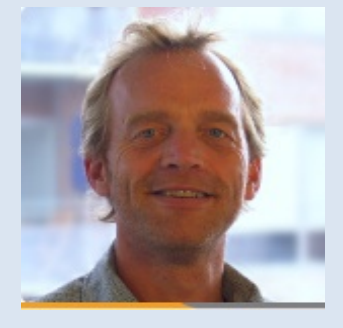

Mads Bo-Krisensen er ansat som udviklingskonsulent på Videnscenter for Integration (www.vifin.dk). Har de senere år forsket i og udviklet andetsprogsdidaktisk it. Er pt. bl.a. koordinator for EU Socialfondsprojektet "Mobil Efteruddannelse".

Niels Ole Ankerstjerne er it-udvikler på Videnscenter for Integration $i$ Vejle (www.vifin), og har deltaget $i$ en lang eog m-læringsprojekter, herunder e-læringsportalen Dansk.nu (www.dansk.nu)

Anne Chresteria Neutzsky-Wulff er videnskabelig assistent på Elementarkursus i Græsk \& Latin, SAXO-Instituttet, Københavns Universitet, hvor hun udvikler fjernundervisning inden for det sprogdidaktiske område. Projektet er delvist finansieret af IT-og Telestyrelsens e-læringspulje.

Herluf Schelde er underviser på sprogcentret LærDansk $i$ Århus. Har senest udviklet og undervist på en onlineuddannelse i dansk som andetsprog http://www.laerdansk.dk/aarhus/dk/netdansk/

\section{Abstract}

Denne artikel præsenterer og diskuterer et m-læringsdidaktisk scenarie til fremmedsprogsundervisning på videregående uddannelser. Scenariet er et bud på, hvordan mobilen og web 2.0 kan inddrages i undervisningen. Scenariet kaldes for Mobil city-og sprogguides og er en kombination af mobilt internet, GPS, Google Maps og geotagging. Fokus er på, hvordan 
mobilen og nettet med deres nye udviklinger kan anvendes til at skabe forbindelser mellem det formelle undervisningsrum og de uformelle læringssituationer uden for rummet. Disse mobile og internetbaserede forbindelser er med til at "guide" den studerende ind i fremmedsproget og de kontekster, det skabes i. Artiklen præsenterer et eksempel på, hvordan Mobile city- og sprogguides kan anvendes på en studietur til et af fremmedsprogenes storbyer.

\section{Mobil og web i hverdagen}

Flere og flere studerende anvender mobiltelefoner i både hverdags- og studieliv (Chen 2007). Det er telefoner med gode lyd- og videoafspilningsmuligheder. Mange af telefonerne har bredbåndsadgang til internettet. Gennemsnitligt udskiftes en mobiltelefon hver 18. måned. Det er også cirka den hastighed, hvormed afgørende fornyelser af telefonernes funktioner sker.

De studerende anvender mobilen i deres hverdag. De tager fotos af venner og steder, de besøger. De sender billeder via MMS til venner eller sender dem til fototjenester på nettet, hvor venner kan se dem. De henter og afspiller mediefiler, herunder musik og små videofilm. De går på nettet og tjekker deres mail og deres studiefora. Hvis de ønsker at finde vej, kan de bruge Google Maps via deres mobil. Bortset fra datatransporten er de fleste populære mobile tjenester gratis. I Danmark vælger mange unge den stationære internetopkobling fra og foretrækker at sende og modtage data udelukkende over deres mobil. Internettet har med andre ord bevæget sig fra at være "stationært" til "mobilt" (Alby 2008a).

Sprogstuderende inddrager internettets nye muligheder i deres hverdag. Der er en bevægelse fra Web 1.0 til det mere brugerorienterede Web 2.0. Her finder man en lang række måder at organisere indhold og interaktion på (Alby 2008b). I stedet for tunge hjemmesider ser man nu en enorm udbredelse af blogs, mobile blogs og video-blogs, hvor brugerens interaktion med siden og andre brugere er i fokus. Web 2.0 handler om fælles skabelse og deling af information og viden via "social software", f.eks. wikier, Flickr, Facebook, YouTube, Google Earth, Google Maps etc.

Bredbåndsmobilen, mobilt internet og socialt software er (eller vil blive) en del af sprogstuderendes hverdag. Spørgsmålet er, om og hvordan fremmedsprogsuddannelserne kan udnytte disse hverdagsteknologier i undervisningen. Det vil blandt andet afhænge af, om uddannelsesinstitutionerne og deres undervisere kan se, at teknologierne kan imødekomme centrale sprogdidaktiske udfordringer

En af de helt store udfordringer for fremmedsprogsundervisere er, hvordan de skaber forbindelse mellem det formelle læringsrum, hvor 
undervisningen foregår, og hverdagens mere uformelle læringsrum. Der er i f.eks. fransk og italiensk behov for at skabe forbindelser mellem undervisningen og den sproglige virkelighed, hvori disse sprog tales. De studerendes mundtlige sprogtilegnelse må hente kommunikativt orienteret autentisk og selvoplevet input fra den virkelighed, hvor sproget tales (van Lier 2007). Den studerende kan selv indhente input under studieture eller i samtaler i Danmark med herboende brugere af målsproget. Vi ved, at de kommunikative situationer, hvori den studerende selv er deltager, er afgørende for sprogtilegnelsen. Men hvordan registreres og fastholdes det autentiske, selvoplevede sprog?

Mobile city- og sprogguides er et sprogdidaktisk m-læringsscenarie, hvis formål er at skabe forbindelser mellem det uformelle læringsrums kommunikative input og det formelle læringsrums mere systematiske overvejelser og kategoriseringer.

\section{Et fremmedsprogsdidaktisk scenarie}

Vi præsenterer i denne artikel et fremmedsprogsdidaktisk m-læringsscenarie, som er under udvikling. Det er oprindelig udviklet på Videnscenter for Integration (www.vifin.dk) til andetsprogsundervisning, men interessen har været stor også fra fremmedsprogsuddannelserne ${ }^{1}$. Scenariet har endnu ikke været afprøvet og undersøgt i fremmedsproglig praksis. Derfor begrænser denne artikel sig til fokus på scenariets didaktiske design.

Vi indleder med at præsentere og kort diskutere det læringsteoretiske rationale bag mobile city- og sprogguides. Her skelner vi mellem et kognitivt, et kollaborativt og et eksistentielt perspektiv på læring (Illeris 2007). Disse perspektiver kan ikke adskilles, men for eksemplets skyld forfølger vi det kognitive perspektiv i demonstrationen af, hvordan vores læringsteoretiske overvejelser udmøntes i scenariets sprogtilegnelsesaktiviteter.

Herefter præsenterer vi kort begrebet geotagging, der er betegnelsen for den teknologi, hvormed man kan placere tags (mærker) i fx Google Earth eller Google Maps. Med geotagging kan den studerende og underviseren markere og afbilde (i tekst, lyd, billeder og video) steder og færden i et sprogligt relevant geografisk område. Geotagging er med andre ord en

\footnotetext{
${ }^{1}$ I efteråret 2008 har der på Center for undervisningsudvikling, Aarhus Universitet, været afholdt temadage om Mobile city- og sprogguides anvendelse i fremmedsprogsuddannelser. Her deltog universits- og gymnasieundervisere. Blandt deltagerne var der stor interesse for at inddrage mobilen $\mathrm{i}$ undervisningen på nye måder. Forbeholdene gik på, om elever og studerende har mobiler med internet. Man var dog enige om, at dette blot var et spørgsmål om tid. I forvejen har de fleste mobiltelefoner med lyd, foto og videooptagemuligheder af god kvalitet.
} 
mulighed for at sætte eller følge spor i det uformelle læringsrum, hvorfra man ønsker at bevare eller registrere input til brug for mere formelle læringsaktiviteter.

Efterfølgende inddrager vi et konkret eksempel på læringsaktiviteter omkring geotagging af sprogligt input. Vi viser i oversigtsform, hvordan fremmedsprogsuddannelserne kan inddrage mobile city- og sprogguides på studieture til for eksempel Paris eller Madrid.

Vi afslutter artiklen med en kort sammenfatning og diskussion af de muligheder og begrænsninger, som et m-læringsscenarie af denne karakter repræsenterer.

\section{Det læringsteoretiske rationale}

Vi ved, at fremmedsprogsstuderende lærer alene. De lærer også sammen med andre, og de lærer det, som er meningsfuldt for dem (Illeris 2007). Det individuelle perspektiv kaldes i fremmed- og andetsprogstilegnelsesforskningen for kognitivt (Ellis 2008). Når man iagttager læring, der foregår sammen med andre, er der tale om et socialt eller kollaborativt og situeret perspektiv på læring (f.eks. Wenger, McDermott \& Snyder 2002). Når det drejer sig om meningsfuldhed i læringen, taler man om et eksistentielt perspektiv (f.eks. Jarvis 2006). Man kan ikke adskille de tre perspektiver i praksis. Derfor må man inddrage alle tre perspektiver i udviklingen af f.eks. mobilbaserede læringsaktiviteter. I denne artikel har vi dog valgt at isolere det kognitive perspektiv for at illustrere, hvordan læringsteori er blevet anvendt i udviklingen af scenariet. Vi beder læseren selv iagttage det sociale og det eksistentielle i de aktiviteter, vi præsenterer, men vil dog knytte en et par kommentarer til disse læringsperspektiver.

Kognitiv andetsprogstilegnelsesforskning har forskellige modeller til at forstå kognitive læreprocesser. Der er informationsteoretiske og systemteoretiske, hermeneutiske og fænomenologiske modeller (Bo-Kristensen 2004) Her vil vi pege på tre centrale processer, som disse modeller har tilfælles:

- forforståelse

- opmærksomhed

- anvendelse

Forforståelsesbegrebet vedrører det, den sprogstuderende har med sig. Det er de erfaringer, den viden og de færdigheder, den studerende lægger til grund for sin tilegnelse. Opmærksomhedsbegrebet er hentet fra perceptions- og bevidsthedsforskningen og er gennem flere år fremhævet som forudsætning for sprogtilegnelse (Schmidt 1990). At lære et sprog indebærer, at man lægger mærke til dets fænomener for at kunne optage dem i korttidshukommelsen. 
Endelig er anvendelse et begreb, som ligeledes stammer fra hukommelsesforskningen og som viser, at vi ved at anvende det netop lærte sprog får mulighed for at bearbejde og lagre det til senere brug - i langtidshukommelsen.

Hvis mobile city- og sprogguides skal afspejle de tre kognitive læreprocesser, må processerne udmøntes i tre aktivitetstyper (Bo-Kristensen 2006):

- før-aktiviteter

- (hoved-)aktiviteter

- efter-aktiviteter

En før-aktivitet skal mobilisere den studerendes forforståelse om et givet sprogligt emne. Når en studerende først er blevet bevidst om, hvad han eller hun ved i forvejen, vil det være enklere og mere udbytterigt at gå i gang med hovedaktiviteten, som skal give den studerende mulighed for at tilegne sig ny viden. Denne tilegnelse foregår i en aktivitet, hvor det drejer sig om at rette sin opmærksomhed mod nye fænomener i sproget. Det er kun den studerende, der for alvor kan afgøre, hvad der er nyt. Undervisningen må tilrettelægges sådan, at den studerende har de bedste muligheder for at lægge mærke til de nye sider af målsproget.

Der er grænser for, hvor meget ny sproglig viden, den studerende kan tilegne sig, uden at han eller hun får mulighed for at forankre sin nye viden. Til slut for at sikre at det nye "gemmes" - må den studerende gennemgå endnu en aktivitet. Denne aktivitet, som skal sikre bearbejdelsen i

langtidshukommelsen, kræver at den studerende bruger det, han eller hun har lagt mærke til. Denne efter-aktivitet kan have mange former og indhold. Det afgørende er, at den studerende får mulighed for at bruge de nye sproglige fænomener og på den måde få et kognitivt "ejerskab" over dem.

Disse tre aktivitetstyper ser vi allerede i megen formel fremmedsprogsundervisning. Her opererer man i lytte-, tale-, læse- og skrivedidaktikkerne med før-, under- og efter-aktiviteter (f. eks. før-lytning, lytning og efterlytning). Men hvorfor ikke udvide disse aktiviteter til de studerendes uformelle læringsmiljøer? En udfordring for alle sproguddannelser er, hvordan der skabes relevante forbindelser mellem et undervisningstilrettelagt (og formelt) fokus og de potentielt mange erfaringer, de studerende kan gøre sig med at lytte, tale, læse og skrive målsproget i autentiske (og uformelle) læringsmiljøer. Denne udfordring vil vi gerne tage op ved at foreslå mobile city- og sprogguides. Inden vi viser, hvordan disse guides kan anvendes i fremmedsprogsdidaktisk praksis, vil præsentere et centralt begreb i denne forbindelse, nemlig geotagging. 


\section{Geotagging}

Geotagging betegner den aktivitet, hvorved man placerer tags (mærker) enten via GPS eller afmærkning direkte i f.eks. Google Earth (figur 1) eller Google Maps. Geotagging repræsenterer en måde at markere en læringskontekst på. Det, som interesserer os ved geotagging, er muligheden for at markere og afbilde steder og færden i et geografisk område, f.eks. en storby i målsprogslandet. Det drejer sig om geografiske områder, der indeholder de uformelle rum, fremmedsprogsuddannelserne traditionelt set ønsker at skabe forbindelser til.

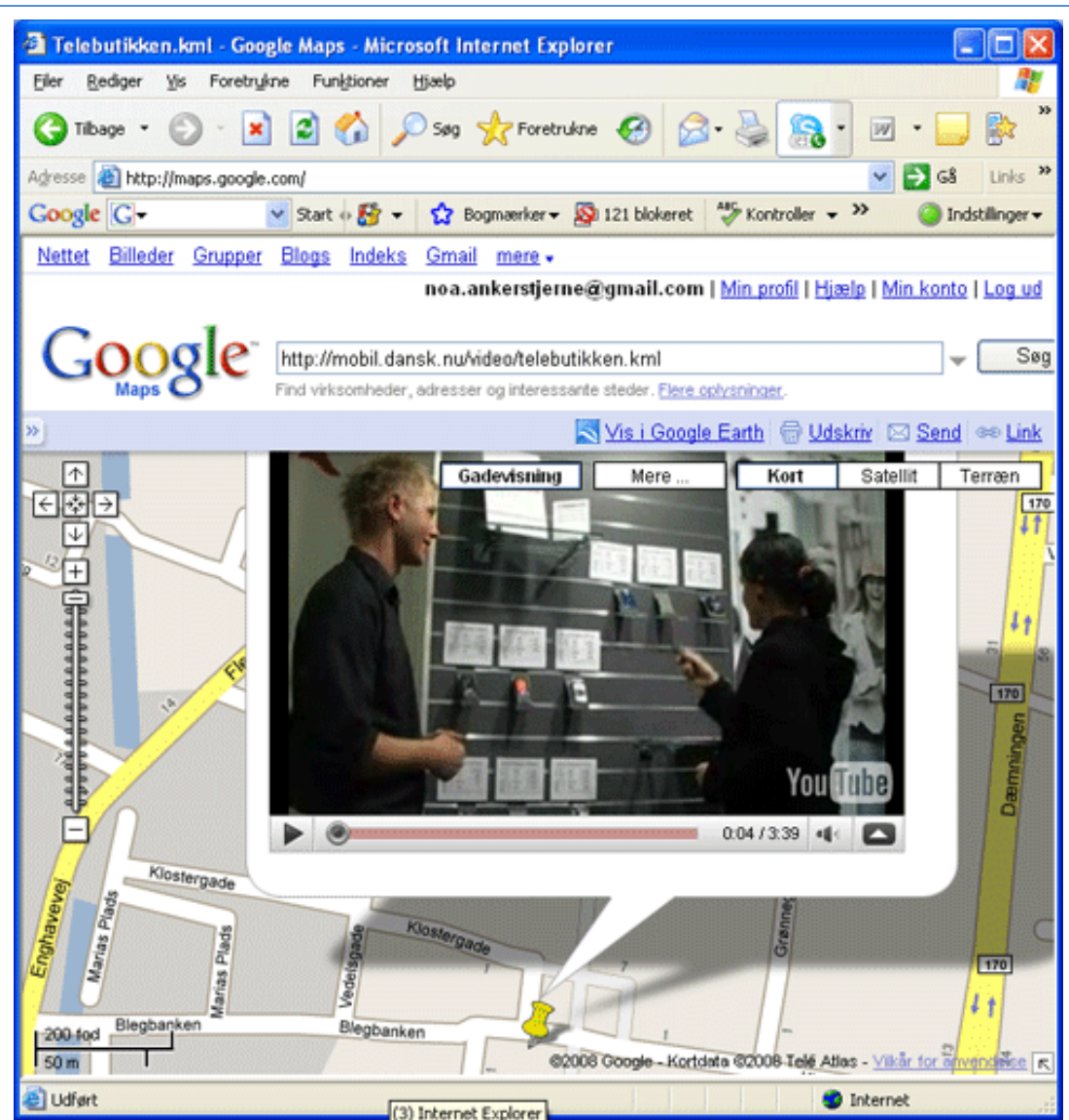

Figur 1. Geotagging. Et tag (i dette tilfælde en tegnestift) placeret på et Google kort (Google Maps). Dette tag indeholder et link til en YouTube film, hvor en køber og en ekspedient fører en samtale om køb af en mobiltelefon. Tag'et kan også indeholde tekst og fotos.

Når studerende geotagger geografiske steder i et uformelt læringsmiljø, "fastholder" de stederne til brug for mere formel sproglig bearbejdelse (figur 2). Tags tilføjes links, tekst, lyd, bilede og video, som illustrerer læringsmiljøets sproglige og kulturelle indhold. Flere tags i et geografisk område, f. eks. en storby, udgør en mobil city- og sprogguide. Det er en 
guide, som skabes både før, under og efter opholdet i det uformelle læringsmiljø. Undervejs inddrager den studerende sin mobils medieoptagere til at indhente lyd, billeder og video af sprogligt og kulturelt indhold.
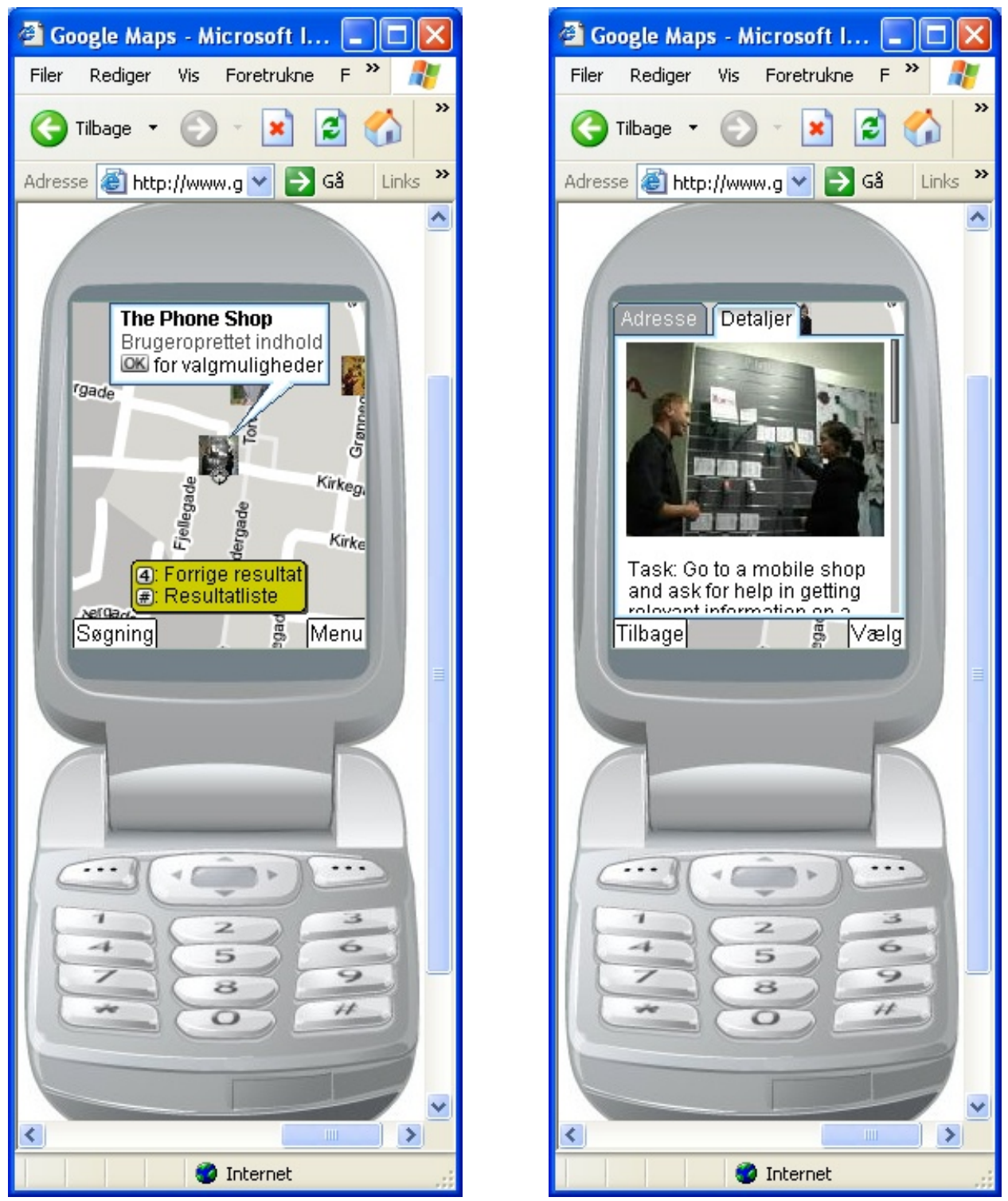

Figur 2. a) Google Maps til mobil, b) et tag, der er åbent. Samme tag som i figur 1.

Kort og tags kan den studerende tilgå fra sin pc eller mobil. Det er også muligt at lave egne tags enten via sin mobil eller pc og på denne måde fastholde og eventuelt dele sproglige oplevelser og erfaringer med andre. Sprogstuderende kan lave egne tags og ruter, eller de kan hente informationer, viden og opgaver via tags, som underviseren eller andre har lavet. 


\section{Mobile city- og sprogguides}

I dette afsnit giver vi et eksempel på, hvordan

fremmedsprogsuddannelserne kan inddrage mobile city- og sprogguides.

Det gør vi ved at tage et oplagt eksempel, nemlig en uges studietur til en storby. Det kunne være Madrid, Paris, Berlin eller Rom.

Studieture i forbindelse med sproguddannelser har fokus på studiet af målsproget og den kultur, det er indlejret i. Fra nogle få dage til flere måneder har den studerende mulighed for at komme tæt på sprog og kultur og undersøge, hvordan de fænomener, man beskæftiger sig med i formel læringssammenhæng, udfolder sig i virkelighedens sproglige praksis. Til forskel fra andetsprogsundervisning, hvor målsproget tales lige uden for det formelle undervisningsrum, er man i fremmedsprogsundervisningen i nogen grad henvist til at opsøge målsproget uden for landets grænser. Når man opholder sig i målsprogssamfundet, befinder man sig i en uformel læringskontekst, hvor man har rig lejlighed til at rette sin opmærksomhed mod nye fænomener i sproget. Det er kun den studerende, der for alvor kan afgøre, hvad der er nyt, men den formelle uddannelse kan hjælpe med studieturens tilrettelæggelse, så den studerende har de bedste muligheder for at lægge mærke til de nye sider af målsproget. I dette afsnit ser vi, hvordan mobile city- og sprogguides kan være en sådan hjælp.

En studietur kan have fokus på mange sproglige fænomener. Vi vælger her at gøre eksemplet så konkret som muligt. Et hold skal på studietur og har arbejdet med en række interaktionelle fænomener og deres sproglige udtryk. Det drejer sig om samtalens grammatik, dvs. hvordan indleder og afslutter de talende en samtale, hvordan skaber de samtalens lytterpositioner osv. Lad os for eksemplets skyld fokusere på samtalens lytterpositioner, som er noget af det, holdet skal undersøge på deres studietur.

En "lytter" i en samtale anvender en lang række verbale og nonverbale udtryk. Nonverbalt drejer det sig om mimik, gestik, pauser osv. Verbalt kan lytteren udtrykke sig med alt fra småord til længere ytringer, der angiver modtagelse, vurderinger og opfordring til fortsættelse af de informationer, taleren leverer. Interaktionel lingvistik ser samtalen som en social aktivitet, hvor deltagerne i fællesskab konstruerer samtalens mange forskellige sproglige aktiviteter (f.eks. Steensig 2001). En af disse aktiviteter er den, som vedrører dannelsen af samtalens emner. Ethvert emne har en ejer (en "taler"), som får sproglig og ikke-sproglig hjælp af en "lytter" til at udfolde sit emne (Bo-Kristensen 2004). Samtalens lytter indtager en vigtig position i samtalen, og iagttagelse af positionens guldgrube af interaktionelle muligheder er noget, enhver studietur bør have fokus på. Inden holdet tager af sted, må underviseren give mulighed for før-aktiviteter, der 
etablerer forhåndsviden om samtalens lytterpositioner. Det gøres ved at præsentere nogle korte, filmede autentiske samtaler, der illustrerer, hvad en lytter kan sige og gøre i en samtale på målsproget. Med udgangspunkt i interaktionel lingvistik undersøger de studerende, hvordan lytterudtryk indgår i dannelsen af samtalen. På denne måde skaber føraktiviteterne en forforståelse, som vil kunne bruges, når de studerende på den kommende studietur opsøger uformelle læringsrums lytterudtryk.

Underviseren introducerer de studerende for Google Maps, hvor der er markeret nogle steder i den by, hvor eksempel-samtalerne har eller kunne have fundet sted. Disse tags indeholder links til eksempelsamtalen. Dette link kan henvise til YouTube eller en hjemmeside, hvor samtalerne er placeret. I tag'et er der ligeledes et resumé af samtalen samt en liste over samtalens lytteudtryk og pointer i forhold til deres dannelse.

På studieturen, som udgør forløbets hovedaktivitet, skal de studerende inddrage deres mobil til at rette deres opmærksomhed mod de målsprogssamtaler, de møder i løbet af turen. De skal iagttage (rette deres opmærksomhed mod) og dokumentere mindst to samtaler, de selv indgår i. De kan eventuelt have aftalt, hvilke steder og hvilke samtaler de vil indgå i. Eller de kan lade tilfældigheden råde og registrere samtaler, som de i situationen vurderer som særligt interessante. De kan bruge deres mobil til følgende:

- Tage fotos af den eller de personer, de samtaler med

- Sende fotos til Google Maps, hvis de har en mobil, der tillader dem at GPS-tagge billederne.

- Lydoptage deres samtaler

- Videooptage deres samtaler

- Indtale - eller få en indfødt til at indtale - lytteudtryk, man har lagt mærke til

De studerende har følgende hjælp til rådighed:

- Eksempel-filmene, som kan downloades til deres mobil

- Google Mobile-kortet med tags og tilhørende ordlister og links

- Evt. andre ressourcer, f.eks. elektronisk udtalevejledning, minigrammatik og ordbog

Datatrafik i udlandet er stadig dyrt. Teleselskaberne har indtil for nylig selv kunnet afgøre prisen på "roaming", dvs. hvad det koster at anvende et fremmed lands tele- og dataydelser, mens man opholder sig i landet. Det indebærer, at studerende desværre en tid endnu må vente med at up- og downloade tekst, lyd, fotos, video og links til og fra deres Google-kort og tags direkte via deres mobil, mens de er på studieture. Dog er der den 
mulighed, at de via internetcaféer eller hotellets internetadgang kan håndtere at up- og downloade informationer.

Når de studerende er hjemme efter studieturen, vil de kunne indgå i en lang række efter-aktiviteter både individuelt og på tværs af holdet. Hvis det ikke har været muligt at uploade deres indsamlede registrering af lyttepositioner i målsprogssamtaler under turen, vil de indlede med at gøre det. Holdet kan skabe en fælles mobil city- og sprogguide gennem eksempelvis Paris. I efteraktiviteter kan de udbygge den mobile city- og guide ved at tilføje:

- Transskriptioner af samtalerne (eller særligt interessante sekvenser i samtalerne)

- Lister af lytterudtryk

- Fotos fra de stæder og de personer, der deltager i samtalerne

- Videosekvenser

- Links til relevante informationer om de steder, samtalerne har fundet sted

- Osv.

Vi indledte med at skitsere tre læringsteoretiske perspektiver på fremmedsprog: Et kognitivt, et kollaborativt og et eksistentielt. Vi har i artiklen forfulgt det kognitive, selvom dette naturligvis ikke kan isoleres fra de to andre. I forbindelse med mobile city- og sprogguides er kollaborativ læring både før, under og efter en studietur meget oplagt. Den fælles forberedelse, samarbejdet om at indhente sprogligt indhold samt den afsluttende bearbejdelse af indhold har åbenlyse kollaborative kvaliteter. Spørgsmålet om meningsfuldhed (det eksistentielle perspektiv) står centralt i refleksionerne over disse guides' formål og anvendelsesmuligheder i den studerendes uddannelse. I et sociokognitivt sprogtilegnelsesperspektiv (f.eks. Atkinson 2007) kan man sige, at tilegnelsens meningsfuldhed og kognitive processer er integreret i de sociale eller kollaborative processer, som fremstillingen af fælles mobile city- og sprogguides repræsenterer.

\section{Sammenfatning}

Mobile city- og sprogguides er et fremmedsprogsdidaktisk mlæringsscenarie, der er ramme om nye former for forbindelser mellem formelle og uformelle læringsrum. Det er centralt for både fremmed- og andetsprogsuddannelser, at disse forbindelser etableres, så de studerende kan udnytte det læringspotentiale, de uformelle læringsrum repræsenterer.

Datatrafik i udlandet er desværre stadig for dyrt til at mobilt internet kan udnyttes fuldt ud, selvom perspektiverne for kombinationen af mobilt 
internet, Google Maps, tags og GPS på studieture synes store. Enhver, der har slået sin internetbrowser til i udlandet blot nogle få minutter ved, at prisen på datatrafik stadig er alt for høj. Den fulde udnyttelse af mobile city- og sprogguides' didaktiske potentiale må derfor stadig begrænse sig til de uformelle sproglige læringsmiljøer, de studerende finder inden for Danmarks grænser. Her er det nemlig ikke ualmindeligt, at studerende tegner relativt billige dataabonnementer. Samtidig er det værd at bemærke, at studerende, der under deres studier opholder sig længere tid i et andet land og har lokale telefon- og dataabonnementer, kan opnå det fulde udbytte af disse mobile city- og sprogguides. Det gælder både danske studerende, der studerer i udlandet, og udenlandske studerende, der opholder sig i Danmark, og som lærer dansk.

Et spørgsmål, man med rette kunne stille, er, om det store teknologiske setup er den eneste vej ind i sprogdidaktiske m-læringsscenarier. Kan mindre ikke gøre det, og er tiden moden til at folde teknologien ud som beskrevet i denne artikel? En studietur til en storby i målsprogslandet kunne inddrage enklere m-læringsscenarier. Man kunne f.eks. nøjes med mobile lyd- eller videooptagelser af samtaler, man ønsker at dokumentere. Det ville her være muligt blot at optage samtalerne på mobilen og senere (ved hjemkomsten) bearbejde dem direkte via mobilen. For nogen ville det måske være et godt sted at begynde og derpå overveje, hvordan man kunne inddrage geotaggede registreringer og bearbejdelser.

Et spørgsmål, man ligeledes kunne stille, er, om studerende vil tage mobile city- og sprogguides til sig. Som vi var inde på i indledningen, anvender unge mobilen og andre hverdagsteknologier i stor stil. Spørgsmålet er, om de er villige til at overføre en teknologisk praksis, de udfolder i deres hverdag, til for eksempel fremmedsprogsstudier. Vi ved, at sprogstudierne tilbyder både virtuelle materialer og læringsplatforme. Det, som synes at knibe, er etableringen af solide og kvalificerede "virtuelle" uddannelseskulturer (Bo-Kristensen 2009). En institution kan ikke nøjes med at "tilbyde" materialer og platforme. Den må aktivt integrere og udvikle materialer og platforme (e- og m-læringsplatforme) i sine uddannelser. De studerende har nok at se til og vil næppe bruge tid på teknologi, som ikke er indtænkt i institutionens uddannelses- og læringspraksis. Men den lethed, hvormed studerende anvender computere, internet og mobiler vil kunne udnyttes af uddannelsesinstitutioner, der $\emptyset$ nsker at styrke deres tilbud gennem disse medier.

Mange sprogfag er trængt, hvilket skaber et endnu større behov for nye måder at tiltrække unge på. Det er unge, som anvender mobil- og anden teknologi i deres hverdag. Didaktisk innovation er vigtig for fagene. Hvordan kan man udnytte de unges teknologiske velvilje til at gøre 
fremmedsprogsuddannelserne mere attraktive i en tid, hvor især de små fremmedsprog er trængt?

\section{Referencer}

Alby, T. (2008a). Das Mobile Web. Munich: Hanser Fachbuch.

Alby, T. (2008b). Web 2.0. Munich: Hanser Fachbuch

Atkinson, D. (2007). Toward a sociocognitive approach to second Language acquisition, The Modern Language Journal, Volume 86, Issue 4, s. 525545 .

Bo-Kristensen, M. (2009). E-læring, andetsprog og integration, Sprogforum, nr. 45 (under udgivelse.) (Tema: Sprogfagene i dag).

Bo-Kristensen, M. (2006). "Content Development in Adult Second Language E-learning”, I: Remenyi, D. (ed.) Proceedings of the International Conference on e-Learning, University of Quebec at Montreal, Canada, June 2006. UK: Reading, s. $23-30$.

Bo-Kristensen, M. (2004). Multimediedidaktik i andetsprog for voksne bidrag til andetsprogsdidaktisk forankring af undervisningens multimediedidaktikl. København: DPU (upubliceret ph.d. afhandling).

Chen, Y. (2007). "Extending Family to School Life: College Students' Use of Mobile Phone", Indlæg præsenteret ved The annual meeting of the International Communication Association, TBA, San Francisco, CA.

Ellis, R. (2008). The Study of Second Language Acquisition. Oxford University Press (2. udgave).

llleris, K. (2007). How we learn. London/New York: Routledge.

Jarvis, P. (2006). Towards a Comprehensive Theory of Human Learning. London: Routledge Falmer.

Schmidt, R. (2001). „Attention“, I: P. Robinson (red.), Cognition and second language instruction, s. 3-32. Cambridge University Press.

Steensig, J (2001). Sprog i virkeligheden. Bidrag til en interaktionel lingvistik. Aarhus Universitetsforlag.

Van Lier, L. (2007). The Ecology and Semiotics of Language Learning. Norwell, Massachusetts: Kluwer Academic Publishers.

Wenger, E., McDermott, R. \& W. Snyder (2002). Cultivating communities of practice: A guide to managing knowledge. Harvard Business School Press. 